\title{
The integration between and common prosperity of government and market: China's experience of economic development
}

\author{
Leming $\mathrm{Hu}$ \\ Chinese Academy of Social Sciences, Beijing, China
}

\begin{abstract}
Purpose - The relationship between government and market is the key to the economic development performance of market economy countries. Due to the limits such as the state/market dichotomy, the focus on static allocation efficiency and the ignorance of the diversity of the market economy and the relationship between government and market, economic liberalism and state interventionism can hardly position and explain the role and evolution of government and market in the real world accurately.

Design/methodology/approach - China's economic transition has always adhered to the reform direction of the socialist market economy and the development goal of a modern socialist country as well as the symbiosis and positive and progressive evolution of government and market, blazing a "third way" in handling the relationship between government and market.

Findings - The "China's experience" shows that the key for emerging market economies to achieve good economic development performance lies in whether they can build a new relationship of the mutual integration between and common prosperity of government and market regarding target selection, production organisation, technological innovation, institutional change and regulatory adjustment.

Originality/value - The second part of this paper analyses the inherent defects of economic liberalism and state interventionism as well as the reasons why they can hardly be adopted as the theoretical guidance for emerging market economies to handle the relationship between government and market. The third part analyses how China has transcended the inherent thinking of liberalism and interventionism and shaped the new relationship between government and market through goal-oriented, active and progressive, two-way interactive exploration and practice to ensure the success of China's economic transition.
\end{abstract}

Keywords Government, Market, Mutual integration and common prosperity, China's experience Paper type Research paper

\section{Introduction}

China's economic transition has made remarkable achievements and attracted worldwide attention since China introduced the reform and opening-up policy. Meanwhile, how to "decode the mystery of China's economic development" has been a hot topic in academic circles at home and abroad. Some scholars believe that the success of China's economic development is that of the free market, that is, the success of privatisation, marketisation and liberalisation. Other scholars argue that the success of China's economic development is attributed to "strong state power" and is a victory for state interventionism. However, the achievement of China's economic development depends on multiple factors. From an economic perspective, how to handle the relationship between government and market is the core of China's economic system reform and the key to China's economic development.

(C) Studies on Marxism. Published in China Political Economy. Published by Emerald Publishing Limited. This article is published under the Creative Commons Attribution (CC BY 4.0) licence. Anyone may reproduce, distribute, translate and create derivative works of this article (for both commercial and noncommercial purposes), subject to full attribution to the original publication and authors. The full terms of this licence may be seen at http://creativecommons.org/licences/by/4.0/legalcode. Originally published in Simplified Chinese in Economic Research Journal.

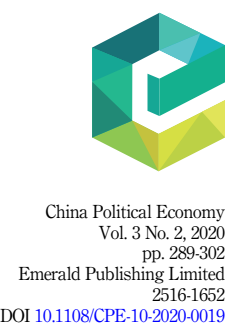


CPE

3,2

290

Hence, it is a feasible theoretical perspective to interpret the "Chinese miracle". However, the above two understandings are trapped in the entrenched ideas of mainstream Western economics and can hardly position and explain the role of government and market in developed market countries accurately, let alone interpret the evolution path and economic development performance of the relationship between government and market in emerging market economies reasonably.

Different from scholars of mainstream Western economic theories Mazzucato (2011) and Reinert (2010), and Genliang (2015) have discovered through long-term research on the history of economy and economic policy that the United States and other Western developed market economies have never truly practised the theoretical boundary of mainstream Western economics on the role of the market and government. The relationship between government and market should be handled "according to whatever the United States does, not what it says." (1) Drawing on the research of the above scholars, the second part of this paper analyses the inherent defects of economic liberalism and state interventionism as well as the reasons why they can hardly be adopted as the theoretical guidance for emerging market economies to handle the relationship between government and market. The third part analyses how China has transcended the inherent thinking of liberalism and interventionism and shaped the new relationship between government and market through goal-oriented, active and progressive, two-way interactive exploration and practice to ensure the success of China's economic transition. The fourth part analyses how the government and the market build a new relationship of integration and common prosperity in target selection, production organisation, technological innovation, institutional change and regulatory adjustment. Finally, this paper points out the main issues that emerging market economies should note when learning from "China's experience" to overcome the limitations of market rationality and government rationality.

\section{Misunderstanding of liberalism and interventionism}

The relationship between government and market is a topic of concern in almost all social sciences. It has been the subject of long-term arguments among economists, during which two major trends of thought have been formed: economic liberalism and state interventionism. While economic liberalism and state interventionism seem to be opposed to each other, there are common cognitive misunderstandings in theoretical logic and analytical thinking regarding the two theories, bringing difficulties for them to position and explain the role and evolution of real-world governments and markets accurately (Hu, 2001).

Although in different historical periods, economic liberalism and state interventionism have various theoretical manifestations, with different understandings within themselves, and the opposition between them has begun to loosen and shown a certain trend of "integration" (Yang and Xie, 2009), their basic tenets remain unchanged. According to economic liberalism, the market mechanism is the only effective means to achieve the optimal allocation of resources in the market economy, and the spontaneous adjustment of the market mechanism can lead to economic prosperity and social progress. There is no so-called public interest as the goal of the government's public policy, and the "social welfare function" is just an illusion; the government is the "incarnation of incompetence, inefficiency, and corruption". Furthermore, whatever the market fails to resolve cannot be properly solved by the government, either, and government intervention will only undermine the normal operation of the economy. Hence, the spontaneous role of the market mechanism should be fully exerted to limit or even minimise the scope of the government's role. On the contrary, state interventionism argues that the effectiveness of the market is conditional, and "the market is not ideal, there is market failure"; there are public interests independent of individuals, and the social welfare function can be logically derived from personal preferences. Also, as a 
representative of public interests, the government can effectively promote the maximisation of social welfare. Therefore, the government's function should be fully exerted to make up for the defects and insufficiencies of the market.

However, the opposition of views does not imply a logical difference. Both economic liberalism and state interventionism regard market and government as entirely separate and independent institutional arrangements and deduce the scope of their respective functions and the potential for mutual substitution directly from the static valuation of the market and government. According to their logic, the market is an internal order of the market economy, while the government is an external force beyond the market economy. The market is an institutional arrangement for providing private goods, while the government is an institutional arrangement for providing public goods. There is an either-or relationship between them: "Government failure" is the theoretical basis for market expansion, while "market failure" is the logical starting point for government intervention. However, from the development history of human society, although the government can certainly be regarded as an external protection organisation established to guard the community against external infringements, it should be viewed more as an internal organisation that allows the community to reproduce, survive and develop. After the Middle Ages, to shake off the fetters of the feudal monarchy on the development of emerging capitalism, the efforts to expel the government outside of "civil society" in the name of "freedom" were rising. The state/market dichotomy gradually became the "golden rule" of mainstream Western economics. In fact, there is no such thing as a completely independent externalised state. The government is not an external organisation that is beyond and separated from economic society. On the contrary, the government and the market are both endogenous institutional arrangements of the market economy society to organise and coordinate the economic activities. The government that is always "there" and "acting", "interfering" in the operation of the market economy as the "external" government, is not the real government. Similarly, the expectation to externalise the government by expanding a clear system of personal property rights and seeking the "market solution" to all economic problems can only be a platonic fantasy.

Since the government and the market are both endogenous institutional arrangements of the market economy society to organise and coordinate the economic activities, the resource allocation in the realistic society must also be the result of integration and interaction between market and government, rather than a process of an either-or choice between them. In economic liberalism, "market omnipotence" is their theoretical basis for advocating laissezfaire, and government failure is their real reason against government intervention. However, if "government withdrawal" is totally based on the perfect order of the market, market failure will become a strong basis for government intervention. It was precisely following the logic of liberals that interventionists such as Arthur Cecil Pigou discovered the existence and position of an "ideal government" in the real world. In fact, the real-world market and government have their respective insurmountable flaws, and the flaws of either party do not logically guarantee that the substitution by the other party will be a reasonable choice. Moreover, the government and the market are not only independent and autonomous but also mutually embedded and symbiotic to some extent. Polanyi (2013) once pointed out profoundly that mainstream economists tended to separate the market from the environment and statically analyse market operations and laws under the assumption that the surrounding environment remained unchanged. However, there is no supportive institutional environment without the involvement of the market. The real-world market must also be "embedded" in society. The purely self-disciplined market and any studies attempting to "disembed" are utopias. Similarly, by using the concept of "public domain", Barzel (1997) explicitly stated that "there are no absolutely exclusive private property rights". In his view, the strength of any individual's rights depends on the efforts made by the individual, others and "third parties" to protect and share this right. Hence, the government must be deeply embedded in the whole

\section{Common prosperity of government and market}

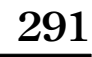


CPE

3,2

292 process of defining, implementing and controlling individual property rights in the market economy. Without the government's "embedding", the market will struggle. There is a complex structural relationship between government and market.

Another common limitation of state interventionism and economic liberalism is that they are both abstract and mechanical short-term static analysis rather than specific and scientific dynamic historical analysis. What they focus on is the connection between the market system and allocation efficiency (also known as "static efficiency" or "Pareto efficiency"). However, there is no theoretical or historical connection between Pareto efficiency and technological innovation or long-term development (Rawski, 2013). For a country, "although the expansion of national income and wealth may be partially achieved through pursuing static efficiency of resource allocation, in order to realise the continuous expansion of national income and wealth, it is necessary to obtain dynamic efficiency of resource allocation (Okuno, 2002). The so-called dynamic efficiency of resource allocation is the development efficiency of a country, which depends not only on the function of the market mechanism but also on the government's role and its interaction with the market. Furthermore, supporting monopolies, state guidance, business alliances, protectionism and other government actions aimed at improving development efficiency rather than making up for market failures to achieve "static efficiency" are precisely essential factors for the long-term economic growth of the United States and other developed countries. In her Entrepreneurial State research, Mazzucato found that the early development of the industries in developed countries such as the United States, which are now in the leading position in the world, benefited from government support. Even today, the governments of developed countries have not upheld the laissez-faire policy; instead, they support the industrial upgrading and technological innovation of enterprises through patent protection, subsidies for basic scientific research, government procurement and other measures (Lin, 2017). However, many government policies in the United States today have been designed to be hidden from public view and implemented through indirect and passive mechanisms rather than direct, highly transparent legislation (King, 2013). "Government invisibility" obscures the role of the government and exaggerates the power of the market; however, it cannot conceal a basic economic fact-liberalism and interventionism are popular as ideologies, but the government and market are always "on the stage" at the same time for long-term development.

Also, both economic liberalism and state interventionism ignore the diversity of the market economy as well as the relationship between government and market worldwide. As the "universal value" of mainstream Western economics, liberalism and interventionism were widely spread around the world. However, they can neither position the governments and markets of western developed market economy countries accurately, nor cover the diverse government-market relationships in various market economy countries. Theoretically, the effective boundary between government and market does not have a fixed equilibrium path or a single static optimal solution, but multiple equilibrium paths and multiple possible optimised dynamic combinations (Chen and Ma, 2013). In other words, there is no uniform, well-defined, fixed boundary between government and market. From a realistic perspective, it is generally believed that the market economy of contemporary developed countries can be divided into three types: the "free market economic model" represented by the United States, the "government-led economic model" represented by Japan and the "social market economic model" represented by Germany. It is clear that neither the Japanese model that advocates the government's role nor the German model that focuses on social equality and long-term benefits can be explained by liberalism and interventionism. Even in the American model, the so-called model of the free economy, the government is not an external "limited government" that only makes up for market failure. American scholar Block (2010) pointed out that the United States is a hidden "developmental network state" concealed by ideology, where the government has long adopted four national actions (i.e. targeted resourcing, opening 
windows, brokering and facilitation) to drive economic development. In fact, the market economy is not just one "standard" model or evolution path. Customs, ideologies, values, cultural ethics and development stages have a crucial impact on the formation and evolution of the market economy and the relationship between government and market. In addition to the above three models, it is easy to see that in the real world, the mature market economy and the developing market economy, the classical market economy and the emerging market economy and the government-market relationship of other market economy countries also differ significantly from the stale "mandatory" abstraction of liberalism and interventionism.

After Adam Smith, economic liberalism became the norm of mainstream Western economics; after the 1929 crisis, state interventionism became the "Bible" of mainstream Western economics; the stagflation in the 1970s made economic liberalisation popular again in the name of "neo"; however, the financial and economic crisis in 2008 and its continued evolution declared the "bankruptcy" of liberalism and interventionism at the same time. Economic history has proved that merely emphasising one side between government and market will inevitably lead to the recurrence of fallacy and the repetition of history. As the mainstream ideology of Western developed countries, liberalism and interventionism, which are alternately popular, can hardly reveal the role of real-world government and market, let alone curing the deeply rooted economic problems in the fundamental contradiction of capitalism. It can be expected that the ideological struggle of opposition and alternation between liberalism and interventionism in Western countries will continue to take place. However, emerging market economies have far more than just two options- to "slip" towards the market-oriented direction with the deregulation of the government or evolve towards strengthening government control, but they have to and can blaze a "third way".

\section{China's practice of government-market relationship}

Undoubtedly, China's reform and opening-up is a historic process where the role of the market continues to expand. However, it is by no means a unilateral process where the government continues to "exit" and be replaced by the market. Based on the historical process of China's economic system reform since 1978, the "China's practice" in handling the relationship between government and market can be roughly divided into four stages for analysis and summary.

In 1978, the 3rd Plenary Session of the 11th Central Committee of the Communist Party of China made a historic decision to focus on economic construction and implement reform and opening up, launching China's practice of handling the relationship between government and market in a new era. Subsequently, the theory of the primary stage of socialism and the basic line of "one central task and two basic points" were gradually established. Based on this guideline, the Communist Party of China, with the persistent pursuit to make the people rich and the country strong, and the Chinese people, with bold explorations in this regard, have continuously driven the evolution of the relationship between government and market. With the deepening of theoretical understandings from "acting in accordance with the laws of economics and emphasising the role of the law of value", "focusing on the planned economy, supplemented with market regulation", to "planned commodity economy", then to "state regulating the market and the market guiding the enterprises", practical explorations such as household contract responsibility system, expansion of local and enterprise autonomy, price system and management measures, labour and wage system reform and development of economic entities of diverse ownership were carried out gradually. As a result, China's economic system has smoothly evolved from the planned economic system in which the government led resource allocation and economic development to a "dual-track system" in which government and market worked together. Before the 14th National Congress of the Communist Party of China in 1992, the proportion of mandatory planned products in the total 
CPE

3,2

294 industrial output value drop to about $16 \%$, that of guided planned products rose about $42 \%$ and that of market-regulated products exceeded $40 \%$.

In 1992, the 14th National Congress of the Communist Party of China proposed to "establish a socialist market economy system", "make the market play a fundamental role in the allocation of resources under the macro-control of a socialist country" and "better exert the strengths of planning and market means". China's practice of handling the relationship between government and market entered a new stage. At this stage, adhering to "benefiting the development of the socialist social productive forces, being conducive to increasing socialist China's overall strength, and helping to improve the people's living standards", China's economic system reform was advancing rapidly. Reforms in the fiscal and taxation, financial and banking, planning management system, investment and state-owned enterprise management systems were continually deepened. The commodity, capital and other production factor markets, as well as the central bank, commercial bank, modern fiscal and taxation systems, were gradually formed. Micro-resource allocation and economic activity were mainly regulated by the market. By 2002, the proportion of government pricing and government-guided pricing in the total retail sales of consumer goods had dropped from $97 \%$ in 1978 to less than 4\%, whereas market-driven pricing accounted for more than $96 \%$. Meanwhile, government functions also shifted from focusing on the direct management of economic activities by administrative means to the adoption of medium- and long-term planning and development strategies and the comprehensive use of economic, legal and administrative means to organise and regulate social and economic activities.

In 2002, the 16th National Congress of the Communist Party of China further proposed "to fully exert the fundamental role of the market in the allocation of resources, and improve a unified, open, competitive, and orderly modern market system”. China's practice of handling the relationship between government and market scaled a new height following China's footsteps of "accession to the WTO". At this stage, to "better exert the fundamental role of the market in the allocation of resources from an institutional perspective", measures such as the reform of the administrative examination and approval system, the administrative management system, the government institutions and the state-owned assets management system were fully implemented. By the end of 2011, the State Council had cancelled and adjusted over $60 \%$ of administrative examination and approval items; various regions had cancelled and adjusted over $50 \%$ of administrative examination and approval items. In this way, on the one hand, the government emphasised more on the use of national plans, programs, as well as industrial, fiscal and monetary policies to guide and regulate social and economic activities; on the other hand, it also paid more attention to the overall coordinated development in the regional, urban and rural, economic and social, human and nature, international and domestic fields and comprehensively mobilised various positive factors to facilitate the scientific development of the market economy. Meanwhile, after the above two stages of government cultivation and promotion, and with the help of the "acceleration" and "incentive" of the general rules of the international market economy, market mechanisms and forces have evolved from continuous "embedding" since the reform to self-expansion and overall construction, hence the gradual establishment of the socialist market economy with Chinese characteristics.

In 2012, the 18th National Congress of the Communist Party of China clearly stated that "we must further respect the laws of the market and better play the role of the government" and "exert the fundamental role of the market in the allocation of resources to a greater extent". China's practice of handling the relationship between government and market entered a new era. At this stage, the reforms of the economic, political, cultural, social and ecological civilisation systems were comprehensively deepened to "let the market play a decisive role in the allocation of resources and the government better serve its duty". Reforms in crucial areas such as state-owned enterprises, fiscal and taxation systems, financial 
systems, land policies and opening up to the outside world were continuously deepened. The negative list system for market access was fully implemented. Various regulations and practices that hindered the unified market and fair competition were cleared and abolished. The price formation and factor allocation market mechanism was improved. The scope and variety of government pricing were further reduced. Importance was attached to developing a mixed-ownership economy, promoting state-owned capital to be stronger, better and bigger, focusing on strengthening the government's own reforms and performing government functions fully and accurately. Attention was paid to using innovation policies and development strategies to guide supply-side structural reforms and development vitality of microeconomic entities. The government and the market were demonstrating a development trend of symbiosis and common prosperity.

The transition was once a common challenge faced by socialist countries such as the former Soviet Union and countries of Eastern Europe. Different from countries that have accepted the "Washington Consensus" and "Shock Therapy" widely praised by neoliberalism economics, China has boldly explored and built a socialist market economy based on the national reality, focusing on the relationship between government and market, the core issue of economic system reform and the key factors of economic development. China has broken free of the stale dogma of economic liberalism and state interventionism and successfully embarked on its own path of transition, providing important inspiration for emerging market economies.

First, China has always adhered to the reform direction of the socialist market economy and the development goal of a modern socialist country in the economic transition. There is a widespread view that "the series of events leading China to a modern market economy was not purposeful artificial plans" and that China's economic transition was "unexpected results of human behaviour" (Coase and Wang, 2013). In fact, China's economic transition had clear direction, goals and advancing logic from the very beginning, as pointed out by Cai (2014) and Zheng (2010). At the beginning of reform and opening up, China established a marketoriented reform direction and development goals of a modernised country, which were embodied in specific and popular terms in life, based on a profound reflection on the drawbacks of the traditional planned economic system and a clear understanding of the reality in the primary stage of socialism. Thereby, China was quickly building a social consensus that led various resources and forces to engage in transition actively. Since then, despite many theoretical critiques and practical challenges, the direction and objectives mentioned above have not changed fundamentally but become clearer and more feasible. Hence, China's economic transition had not only a consistent action guideline at the practical level but also the support and guarantee of the stable and flexible ideology indispensable for success. The historical facts of economic development have demonstrated that for the successful transition of any society, the logical consequences of institutional changes and economic development must be presupposed through ideology to enhance people's extensive recognition of the expected benefits of transition continuously and form mainstream social awareness of universal inclusiveness and continual promotion of transition. Without a successful ideology, it is hard to imagine that China's government can become an authoritative force that effectively drives economic transition, and that market mechanisms and market forces can rapidly expand and become the decisive force in resource allocation.

Second, China's economic transition is a dynamic and stable process led by the government. Regarding the path selection for the transition of the traditional socialist planned economic system, a view widely accepted by mainstream Western economists is that we must implement shock therapy based on the Washington Consensus to bridge the "gap" between the planned economy and the market economy and quickly establish a complete institutional system required for the effective operation of a modern market economy. However, the bitter lessons of failure in the transition of multiple former socialist countries prosperity of government and market

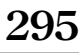


$\mathrm{CPE}$

3,2

296 suggest that the above "Consensus" is just another imperfect "prayer" of religiously pious mainstream Western economists for a "perfect market order". There are two ways of institutional change in human society: radical change and gradual change. However, other than the alternation of old and new social systems, radical changes can hardly achieve the desired performance because they can easily lead to political disorder, economic imbalance and even severe social conflicts. Hence, even Western developed countries had gone through a long process from the nineteenth century to the twentieth century before establishing the so-called mature market economy. Undoubtedly, China has correctly chosen the gradual changes in the economic transition, thus ensuring that the government can effectively grasp the general trend of social and economic development and the big picture of political development, and also allowing the relatively smooth evolution of the market order from government cultivation to self-development. However, gradual changes often lead to institutional vacuum and disorder due to friction cost and time lag. Therefore, there was no lack of "radical" initiatives in the transition of China's economy, which effectively addressed the pressure and challenges from internal and external demand for rapid transition, thus becoming a "positive and gradual change". In this way, the vast scale, profound changes and rapid development of China's economic transition can be coordinated and resolved right here and now (Lin, 2008), providing the dynamic and stable order system required for a successful transition.

Finally, the transformation and development of China's economy is a two-way interactive process with mutual promotion and common development of government and market driven by the state. "Either a bit more market-led or a bit more state-led" is a persistent and unsolvable "theoretical conjecture" of economic liberalism and state interventionism. However, historical analysis and practical experience suggest that: The successful rise of emerging market economies is often closely related to the delimitation of property rights and market expansion vigorously promoted by the government; a more developed market depends more on the government's effective penetration into various aspects such as property rights delimitation, order maintenance and investment environment optimisation; a more effective government is better at introducing market forces and competition mechanisms in areas such as public goods provision, public utility management and even national defence and security; and the functional vacancy of either the government or the market will cost the market economy its due vitality for sustainable development. Drawing on historical experience, the practice of China's economic transition has not fallen into the "theoretical trap" of mainstream Western economics obsessed with the "either-or" dilemma between government and market. Instead, following the "three benefits" and adhering to the concept of "development is of overriding importance", the government and the market of China successfully evolved from a complementary relationship of "sector coexistence" to a symbiotic relationship of "mutual embedding, mutual integration, and common prosperity". Joshua Cooper Ramo, a well-known American researcher on China-related issues, once pointed out vividly that China needed a dan-like national image, one that harmonised opposites: the so-called dan-like means a paradox that integrates the contradiction between "water" and "fire" (Xu, 2008). It is precisely through "harmonious integration, mutual promotion and common prosperity" between government and market, which is regarded incompatible by mainstream Western economics, that China can gain sustained social vitality required for the success of the economic transition.

According to Lin (2008), any form of transition in any society is inseparable from three basic elements - authority, order and vitality, as the presence of authority is the prerequisite of transition; the order is the guarantee of transition and the vitality of the society and people is the internal driving force for a transition. China has gradually established a new type of "mutual integration and common prosperity" relationship between government and market through goal-oriented, active and progressive, two-way interactive exploration and practice 
since the reform and opening-up, providing the authority, order and vitality required for the success of China's economic transition. Nolan (2005), a professor at the University of Cambridge in the United Kingdom, points out that if the so-called third way refers to a creative and symbiotic relationship between state and market, China has been following its own "third way" since 2000.

\section{Mutual integration and common prosperity: new relationship between government and market}

Engels once noted that there might be three circumstances regarding the government's role in the economic development of a country: acting in the same direction as the national economy, thereby driving economic development; acting in the opposite direction, thereby hindering economic development; or hindering economic development in certain directions while facilitating its development in another direction, thereby hindering or driving economic development (Engels, 1972). In other words, government is both "the key to economic growth and the root of human-factor induced economic recession". The transition of China's economy not only has its unique rationale but also follows the general law of the development and prosperity of market economy countries, suggesting a new choice for emerging market economies to handle the relationship between government and market. "China's experience" shows that whether government can play its "decisive role" in driving economic development (instead of hindering it) depends on whether it can establish a new type of relationship between government and market that promotes each other (instead of inhibiting each other) for mutual integration and common prosperity in target selection, production organisation, technological innovation, institutional change and regulatory adjustment.

\subsection{Target selection}

For the economic development of a country, "what to do" is far more important than "how to do" (Jia, 2013). As is commonly acknowledged, regarding "what to do", market selection is superior in its immediacy and flexibility, which can often achieve static efficiency of resource allocation. However, due to its short-term orientation and spontaneity, market selection can easily lead to social and economic imbalances or even long-term development failure. On the other hand, government selection, which is long-term oriented and strategically robust, can often achieve long-term development efficiency; however, government selection failure can result in resource misallocation and impairment to allocation efficiency as well. Therefore, to improve the long-term economic development efficiency of a country, the immediacy of market selection and the long-term orientation of government selection must be unified organically and the short-term efficiency and long-term development goals must also be integrated organically: First, it is necessary to optimise the national long-term development strategy and overall goals. The national long-term development strategy and development goals must comply with and grasp the development laws and trends of the modern market economy based on scientific predictions and, in the meanwhile, reflect and express the interests and concerns of the public through both "top-down" and "bottom-up" interactions. Second, it is necessary to ensure the relative stability and continuity of the long-term planning and policy orientation for national development to shape and stabilise market expectations and guide market selections towards long-term and macroeconomic orientation. Third, it is necessary to build and improve a nationwide, unified market system with information openness which promotes orderly competition, eliminate local protectionism and the "market segmentation" and "information distortion" resulting therefrom, so that market selection can reflect not only the "small goals" of microeconomic entities but also the "medium goals" of local governments and even the "big goals" of the whole country. Only in this way

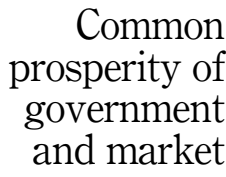


CPE

3,2

can the "coupling" between government and market selection be achieved and the organic combination of the people's current and long-term, local and overall interests be truly realised.

\subsection{Production organization}

The real-world "organisational structure of production" is an organic combination of market and government, rather than a "solo" of a free market. Empirical analyses have revealed the close, intrinsic functional relationships between public capital stock and private capital stock, factor productivity, return on private capital and private investment rate. Government investment can "crowd out" private investment, yet it can also "crowd in" private investment. The increase/decrease of public investment in infrastructure will stimulate/hinder private investment, the improvement of its efficiency and the economic development of the whole country (Aschauer, 1991). Hence, to prosper market and achieve the goal of national economic development, it is necessary to organically integrate the production organisation functions of government and market: First, it is necessary to comply with the objective trend where public goods and expenditures increase with economic development and social progress and effectively exert the role of government in organising production to increase the supply of public goods. These measures not only meet people's demand for income-elastic public goods such as public security, medical care, education and sports but also provide the infrastructure necessary for the expansion of private investment and social production. Second, it is necessary to improve the means of public goods provision and combine the direct and indirect governmental production by guiding private enterprises and market forces to participate in producing public goods so as to improve the supply efficiency of public goods. Third, the regulatory power of a unified national market system should be leveraged to regulate the competitive behaviours of local governments, such as organising and coordinating production activities and guide the rational and orderly flow of various resources among regions. In addition, regarding strategically significant and high-risk emerging industries (Internet economy, digital economy, biotechnology and space technology) and essential fields such as finance, the government must function as a "mega-corporation" to enhance the national resource creation capacity, shift the production possibility frontier of the whole society outward, and meanwhile effectively prevent social capital from being detached from the physical economy and the occurrence of systemic financial risks.

\subsection{Technological innovation}

Technological innovation is the "primary engine" of economic development and strategic support for a country or region to enhance its economic competitiveness. Since innovation activities are a dynamic process characterised by cumulativeness, collectiveness and uncertainty, the formation and development of a country's innovation system can never be achieved through the innovation activities of individual enterprises and market competition. Hence, the long-term and universal presence of innovation policies aimed at promoting the generation and expansion of technological innovation activities and driving the growth and development of the innovation economy in Western developed countries has become an indisputable fact. Moreover, their innovation policies have evolved from "Innovation Policy 1.0" dedicated to addressing market failures and "Innovation Policy 2.0" to addressing system failures to "Innovation Policy 3.0" which focuses on systemic revolution and transformation (Chen,2017). For emerging market economies, to obtain sustained momentum for economically catching-up, they have to integrate and innovate various innovation policies and fully exert the driving effect of government in the field of technological innovation while stimulating the innovation vitality of market: First, government should increase the supply of intellectual, social and institutional infrastructure to provide a good market environment for innovation activities. Second, government should directly allocate public resources to 
increase the effective supply of technological innovation by supporting state-owned enterprises, a vital innovation carrier, while using such demand-side policies as public procurement, consumption subsidy and tax incentive to promote the application and diffusion of new technologies and channel private resources to government-directed fields of innovation. Finally, the innovation activities among various entities and within and between industries should be coordinated through the two-way interaction between government and enterprises to facilitate the formation and development of innovation networks and systems and promote the "disruptive innovation" of the entire social and economic system (Gu, 2017).

\section{Common prosperity of government and market}

299

\subsection{Institutional change}

Institutional arrangements cannot remain static for any country, especially an emerging market economy. It is the very institutional evolution resulting from the continuous interaction between market entities and government that determines the economic growth path of a country, and it ultimately shapes different forms of market economy and determines their performances. Put differently, unilateral actions or spontaneous expansion of either government or market can hardly build an "institutional structure" required for sustainable economic development, and the institutional evolution in emerging market economies seeking to catch up must be powered by the wisdom and strength of both government and market: First, the mainstream social ideology of institutional changes must be promoted by two-way interaction and cohesion between government and market. It is necessary to transform the will of the nation and framework of discourse into the universal value pursuit of the public through effective means and continue to gain the support and loyalty of both new and old interest groups. Second, the optimisation and evolution of various institutional arrangements must be promoted through a two-way interaction between government and market to continuously shape "new" governments and markets. Government and market are not only "main entities" of institutional changes but are also being constantly "reshaped". Government can continuously cultivate and shape market through national actions; reversely, market can also force government to reform through spontaneous expansion. A "disembedding" move by any party seeking unilateral expansion will inevitably lead to the distortion of the relationship between government and market and the failure of institutional changes. Third, the authority, order and vitality critical to the institutional changes under the conditions of the market economy must be provided through the two-way interaction between government and market. Government's ability to control market economy should be continuously improved to gain the sustained authority and order foundation required for driving institutional changes, and the innovation capabilities of market must be further stimulated to gain the "potential benefits" and social vitality needed to promote institutional changes.

\subsection{Regulatory adjustment}

Contrary to the policy claim implied in mainstream Western economics theories that government should be as separated from the private sector as possible to avoid government agencies being controlled by the private sector, modern theories of shaping and creating markets believe that if government tries to drive the transformation of the economic structure by shaping and creating new technologies, new sectors and new markets, then it has to encourage the establishment of close interdependency and new trust relationship between government and market. Government can provide directional guidance and coordination to private actors through its appeal, agents of trust relationships between various economic entities and specific task-oriented policy instruments, etc. (Jia, 2017). In other words, if the goal is not only static allocation but also long-term development efficiency, government and market must be integrated into each other in terms of regulatory 
CPE

3,2

300

adjustment to standardise, guide and encourage the economic behaviours of market entities: First, government and market rules should "fit" with each other to achieve "regulation compatibility". If government's rules "transcend" their market counterparts which are rooted in custom, tradition and mores, it will inevitably lead to distortions in the behaviours of market entities. Market and government rules should be integrated into and co-evolve with each other through social and cultural construction. Second, in line with the development trend of "deconstruction of authority" and "decentralisation" of modern technology, the role of intermediary organisations and "contractual governance" should be fully exerted to build a new governance pattern where government departments and private sectors collaborate and cooperate, i.e. a pattern of "network governance". Additionally, modern information technologies such as big data, cloud computing and artificial intelligence should be used to improve government's regulatory adjustment approach and strengthen "window guidance" for market entities to coordinate economic activities between enterprises and industries and avoid "structural imbalance" due to the response lag in market adjustment.

\section{Postscript}

Historical experience and theoretical analysis suggest that the various theories of economic liberalism and state interventionism seeking to clearly define the scope of government and market based on the state/market dichotomy are all but theoretical assumptions rather than representations of reality. Under their influence, many developing countries over-focused on the power of being "market-driven" but ignored the potential of being "government-driven", resulting in poor performance in economic development. It turns out that government of the United States, an advocate of mainstream Western economics, has been deeply "embedded" in multiple aspects of US social and economic life, thus laying the foundation for its previous and present economic success. China's practice in handling the relationship between government and market also suggests that, in order to achieve the long-term success of economic development, the traditional construct of liberalism and interventionism must be transcended and a new type of relationship must be established between government and market where they are embedded in and enhance each other for mutual integration and common prosperity.

However, we must maintain a clear understanding of market rationality, government rationality and their limitations. The key to the success of China's economic transition lies not in an "authoritarian government" but in the adherence to the leadership of the Communist Party of China and the socialist orientation in development. In China's market economy, the adherence to the leadership of the Communist Party of China and the socialist orientation has provided a fundamental guarantee for maintaining the constant, extensive affinity to the people and orientation towards public good in China's government decisionmaking and behaviours and effectively created and shaped markets. This is not only what makes "China's experience" unique but also what many emerging market economies find difficult to replicate.

Meanwhile, to make up for the limitations of market rationality and government rationality, it is also necessary to strengthen social construction and give full play to the vital role of community governance in the maintenance of a balanced symbiosis among government, market and society. Renowned British political scientist Anthony Giddens once noted that the best form of society is one which strikes a balance among a competitive market, an effective government and a vibrant civil society - excessive market influence can bring about inequality and over-commercialisation; excessive government influence can lead to authoritarianism; excessively powerful civil society can cause social division and conflict (Giddens et al., 2007). 


\section{References}

Aschauer, D.A. (1991), "Jichu sheshi: meiguo de disanzhong chizi [Infrastructure: America's third type of deficit”", (trans. from English by Zhao, C.M. and Chen, X.N.), Guoji jingji pinglun [International Economic Review], Vol. 14 No. 10, pp. 16-22.

Barzel, Y. (1997), "Chanquan de jingji fenxi [Economic analysis of property rights]", (trans. from English by Fei, F.Y. and Duan, Y.C.), In Shanghai Sanlian Shudian [Shanghai Joint Publishing] and Shanghai Renmin Chubanshe, Shanghai People's Publishing House, Shanghai.

Block, F. (2010), "Beiyinxing de Meiguo zhengfu zai keji chuangxin shang de zhongda zuoyong [Swimming against the current: the rise of a Hidden Developmental State in the United States]", (trans. from English by Zhang, W.), Guowai lilun dongtai [Foreign Theoretical Trends], Vol. 15 No. 6, pp. 58-64, Vol. 15 No. 7, pp. 77-91.

Cai, F. (2014), Pojie Zhongguog Jingji Fazhan zhimi [Demystifying the Economic Growth in Transition China], Social Sciences Academic Press (China), Beijing.

Chen, Z. (2017), "Bei "hushi" de chanye zhengce — chuangxin zhengce de yanjin yu weilai ["Neglected" industrial policy - evolution and future of innovation policy]", Xuexi yu tansuo [Study and Exploration], Vol. 39 No. 8, pp. 127-131.

Chen, Y.L. and Ma, Y. (2013), Dajinrong lungang [Outline of the General Theory of Macrofinance, China Renmin University Press, Beijing.

Coase, R.H. and Wang, N. (2013), Bian'ge Zhongguo: shichang jingji de Zhongguo zhilu [How China Became Capitalist], (trans. from English by Xu, Y. and Li, Z.M.), China CITIC Press, Beijing, p. V.

Engels, F. (1972), "In: central compilation and translation Bureau", in Marx, Engels, Lenin and Stalin (Eds), Makesi Enggesi quanji [Karl Marx and Friedrich Engels Collected Works], People's Publishing House, Beijing, Vol. 4, p. 483.

Genliang, J. (2015), Xin lisite Jingjixue zai Zhongguo [New Listian Economics in China], China Renmin University Press, Beijing.

Giddens, A., Ren, J.T., Huang, P. and Wang, M.M. (2007), "Guojia zuizhongyao de touzi shi dui ren de touzi-Jidengsi duihualu [The Most Crucial Investment of a Country is Investment in Human Capital - dialogue with Giddens]”, Nanfang Zhoumo [Southern Weekend], Guangzhou, 20 December 2007.

$\mathrm{Gu}, \mathrm{X}$. (2017), "Zhiliqianruxing yu Chuangxinzhengce de duoyangxing: Guojia-shichang-shehui guanxi zairenshi [Governance embeddedness and the varieties of innovation policy: the statemarket-society relationship revisited]", Gonggong Xingzheng Pinglun [Journal of Public Administration], Vol. 10 No. 6, pp. 6-32+209.

Hu, L.M. (2001), "Gonggong wupin yu zhengfu de zuoyong [Public goods and the function of government]", Caijing yanjiu [The Study of Finance and Economics], Vol. 27 No. 8, pp. 11-16.

Jia, G.L. (2013), "Cong wubainian jingji zhengce shi zhong tanxun guofu guoqiong de aomi [Exploring the secret of rich and poor countries from the five hundred years of economic policy history]", Guowai lilun dongtai [Foreign Theoretical Trends], Vol. 18 No. 3, pp. 109-111.

Jia, G.L. (2017), “Kaichuang dabian'ge shidai guojia jingji zuoyong dataolun de xin'gangling — ping Mazukatuo de qiyejiaxing guojia: pochu gonggong yu siren bumen de Shenhua [Creating a new guideline for discussing the role of national economy in the era of great revolution-review on the entrepreneurial state: debunking public vs. private sector Myths by Mazzucato]", Zhengzhi jingji xuebao [Review of Political Economy], Vol. 8, pp. 123-137.

King, D. (2013), "Meiguo de yinxing zhengfu: yincang guojia de daijia [America's Hidden Government: the costs of a submerged state]", (trans. and adapted from English by Zhang, G.H.), Guowai lilun dongtai [Foreign Theoretical Trends], Vol. 18 No. 3, pp. 114-116.

Lin, S.L. (2008), "Youxiao zhengzhi yu daguo chengzhang-dui Zhongguo sanshinian zhengzhi fazhan de fansi [Effective politics and the growth of great nation: a discussion on China 30 years' political development]", Gonggong xingzheng pinglun [Journal of Public Administration], Vol. 1 No. 1, pp. 38-66, p. 198.

\section{Common \\ prosperity of \\ government \\ and market}


$\mathrm{CPE}$ 3,2

Lin, Y.F. (2017), "Xin jiegou jingjixue de lilun jichu he fazhan fangxiang [Theoretical basis and development direction of new structural economics]", Jingji pinglun [Economic Review], Vol. 28 No. 3, pp. 4-16.

Mazzucato, M. (2011), The Entrepreneurial State, Demos, London.

Nolan, P.H. (2005), "China at the crossroads”, Journal of Chinese Economic and Business Studies, Vol. 3 No. 1 , pp. 1-22.

Okuno, M. (2002), "Si zhang: shichang he zhengfu de hubu guanxi-shichang jineng kuozhangxing zhengce de biyaoxing [Chapter 4: The complementary relationship between market and government - the necessity of policies facilitating market functions]", (trans. from Japanese by Lin, J.B. et al.), in Aoki, M., Okuno, M. and Okazaki, T. (Eds), Shichang de zuoyong, guojia de zuoyong [The Role of the Market, The Role of the State (Chinese Edition)], China Development Press, Beijing, pp. 80-112.

Polanyi, K. (2013), Jubian: Dangdai zhengzhi yu jingji de qiyuan [The Great Transformation: The Political and Economic Origins of Our Time], (trans. from English by Huang S.M.), Social Sciences Academic Press (China), Beijing.

Rawski, T. (2013), "Zhongguo jiqi jingji gaige de linian [China and its philosophy of economic reform]”, (trans. from English by Gong, W.), Guowai lilun dongtai [Foreign Theoretical Trends], Vol. 18 No. 6, pp. 55-64.

Reinert, E.S. (2010), Fuguo Weishenme Qiong, Qiongguo Weishenme fu [How Rich Countries Got Rich and Why Poor Countries Stay Poor], (trans. from English by Yang, H.T. and Chen, G.T. et al.), China Renmin University Press, Beijing.

$\mathrm{Xu}$, J.Z. (2008), "Guowai xuezhe lun Zhongguo tese shehui zhuyi [Studies by foreign scholars on socialism with Chinese characteristics]", Zhongguo tese shehui zhuyi yanjiu [Studies on the Socialism with Chinese Characteristics], Vol. 24 No. 3, pp. 39-51.

Yang, C.X. and Xie, Z.G. (2009), "Guoji jinrong weiji yu Kai'ensi zhuyi [the Global financial crisis and Keynesian economics", Jingji yanjiu [Journal of Finance and Economics], Vol. 44 No. 11, pp. 22-30.

Zheng, Y.N. (2010), Zhongguo moshi: jingyan yu kunju [The Chinese Model: Experience and Dilemma], Zhejiang People's Publishing House, Hangzhou, p. 4.

\section{About the author}

Leming Hu, The Deputy Director of the Institute of Economics, Chinese Academy of Social Sciences and a distinguished professor and doctoral supervisor at the School of Economics, University of Chinese Academy of Social Sciences (Beijing, 100836). Leming Hu can be contacted at: hlmdx@vip.sina.com

For instructions on how to order reprints of this article, please visit our website:

www.emeraldgrouppublishing.com/licensing/reprints.htm

Or contact us for further details: permissions@emeraldinsight.com 